\title{
EXPLORING FACTORS OF STRESS LEVEL IN PARENTS OF CHILDREN WITH AUTISTIC SPECTRUM DISORDER'
}

\author{
Nina STANOJEVIĆ, Vanja NENADOVIĆ, , \\ Saška FATIĆ, Miodrag STOKIĆ2***, \\ ${ }^{*}$ Life Activities Advancement Center, Belgrade, Serbia \\ *Institute for Experimental Phonetics and \\ Speech Pathology „Đorđe Kostić“, Belgrade, Serbia
}

Inaddition to difficultiesinsocialinteractionand communication, children with autistic spectrum disorder (ASD) also exhibit behaviors that interfere with daily activities and are difficult to control, which can lead to disturbances in the household and extended family. The child's limited social, emotional and communicative abilities, their unequal cognitive development and maladaptive behaviors are a source of stress for parents. The goal of our study was to assess the level of stress in parents of children with ASD in relation to gender, education, age of parents, the child's age, and speech and language skills. The sample of this study consisted of 40 parents (20 mothers and 20 fathers) 21 to 56 years of age. All respondents were parents of children with ASD; 22 were parents of children receiving treatment at the Institute for Experimental Phonetics and Speech Pathology "Đorde Kostić and 18 parents were members of the Association of parents of children with autism. In this study, we used The Parental

1 This paper is the result of the research project „Interdisciplinary research of verbal communication quality" ON 178027 financed by the Ministry of Education, Science and Technological Development of the Republic of Serbia

2 E-mail: m.stokic@iefpg.org.rs 
Stress Scale (Berry \& Jones, 1995) to assess the level of stress among parents. The results show that there are no statistically significant differences in the level of stress in relation to parental sex, parental age, the child's age and child's expressive language development. We found a statistically significant effect of parental education level ( $p=0.005)$, child's receptive language development $(p=0.008)$, and child's verbal communication development $(p=0.015)$ on parental stress level. Parental lower education level, child's inability to understand speech, and undeveloped verbal communication of the child can lead to greater parental stress. The stress of parents can significantly complicate and slow down the process of child rehabilitation. It is important to know that it is equally necessary to support fathers and mothers, parents of all ages, parents of children of all ages and different speech and language skills and that particular attention should be given to parents with lower education.

Key words: autistic spectrum disorder, parental stress, children's communication skills

\section{INTRODUCTION}

Autistic spectrum disorder (ASD) represents a neurodevelopmental disorder characterized by deficits in social communication and social interaction, including deficits in social reciprocity, non-verbal communication and the ability to develop, maintain and understand relationships (American Psychiatric Association - DSM-V, 2013). Other characteristics are the presence of a restricted, repetitive and stereotyped repertoire of behavior, interests and activities (American Psychiatric Association - DSM-V, 2013). In addition to difficulties in social interaction and communication, children with ASD exhibit behaviors that interfere with daily activities and are difficult to control, which can lead to disturbances in the immediate and extended family.

The child's limited social, emotional and communication skills, its uneven cognitive development and maladaptive behaviors are a source of enormous stress for parents (Hastings \& Johnson, 2001; Milačić Vidojević, 2008). Deficit in social skills has been identified as one of the best predictors of the level of stress in parents of these children. The factors inducing 
mothers' stress include dysfunction in the field of eating and sleeping habits, as well as emotional dysregulation, while in case of fathers, the stress is usually caused by inadequate behavior of the child (Davis \& Carter, 2008). Davis and Carter (2008) assumed that this is due to the fact that mothers are more concerned about the child's daily activities, while fathers are more concerned with the behavior manifested in a public place. Meirsschaut, Roeyers, and Warreyn (2010) found that mothers experienced significantly higher levels of stress in connection with their child with ASD, compared to their child with typical development. Mothers of children with disabilities face higher risks for developing health and psychosocial problems (Duarte, Bordin, Yazigi \& Mooney, 2005). These authors specifically state that the factors which jointly contribute to increasing stress of mothers of children with ASD are: weaker attachment of the child, the child's lack of interest in other people, the situation when the mother is older, and the child is younger. It has been shown that parents of children with ASD experience higher levels of stress and lower levels of parental competence than parents of children with typical development (Hastings et al., 2005; Ingersoll \& Hambrick, 2011). Some authors compared the stress levels of parents of children with ASD and other types of disability (Eisenhower, Baker \& Blacher, 2005; Estes et al., 2009), especially parents of children with Down syndrome (Dabrowska \& Pisula, 2010). They found that parents of children with ASD have the highest level of stress. Children with ASD are a heterogeneous group, which creates a challenge for parents and professionals who are sometimes careless toward parents' concerns. In addition, diagnostic procedures can take years. Meanwhile, the variety of symptoms of ASD prevents the construction of a standardized treatment plan and parents are faced with the responsibility of selecting a proper treatment for their child without being able to obtain more information about the prognosis of the development of their child, which altogether leads to high stress levels (Ogston, Machintosh \& Myers, 2011; Wachtel \& Carter, 2008). In contrast, Down syndrome can be diagnosed 
at birth using phenotypic and genetic tests, and the prognosis is less variable than in the case of ASD.

Although the majority of studies examined an association between child's behavioral problems, ASD symptoms severity, and social-emotional skills with the parental stress level, this study was focused on exploring the association between child's verbal abilities and parental stress level. The first symptom that parents most frequently notice about their child is undeveloped speech, and it is also the most common reason why they see a specialist. Some children with ASD never develop speech, some develop speech, but due to the deficit of social communication never learn to use it functionally, while a number of children with milder forms of ASD master verbal communication. More specifically, Klinger, Dawson, and Renner (2002) found that approximately $25 \%$ of children with ASD never develop functional speech. It has been shown that young children with ASD do not show the same interest in speech as their peers with typical development (Kuhl, Coffey-Corina, Padden \& Dawson, 2005). Interest in speech plays an important role in the acquisition, understanding and processing of speech, as well as the development of oral communication. It is important to point out that the auditory and verbal processing are embedded in the wider context of social communication, so it is understandable why people with ASD have impaired expressive and receptive language, as well as understanding of the emotions and intentions of others, which leads to disorders of speech and language as one of the main features of ASD. When a younger child is diagnosed with ASD, the parents, because of the reasons stated above, do not know exactly what to expect. Coupled with failure to understand the child's wishes and needs, this leads to additional stress, which interferes with the habilitation and rehabilitation of the family and of the child. Tomanik, Harris and Hawkins (2004) found an association between a higher maternal stress level and child's inability to communicate and interact with others. McStay and colleagues (McStay, Dissanayake, Scheeren, Koot \& Begeer, 2014) investigated only the association between verbal abilities 
and stress level of mothers of children with high-functioning autism, and did not find a connection. Contrary to these findings, Konstantareas and Papageorgiou (2006) found that mothers of verbal children were less stressed compared to mothers of non-verbal children.

We wanted to investigate how some demographic characteristics of parents and verbal abilities of children are associated to stress level. The aim of our study was to assess the level of stress in parents of children with ASD in relation to parental sex, education level, and age, as well as in relation to child's age, and speech and language skills (development of expressive/receptive language, and the use of language for communication).

\section{METHODOLOGY}

Sample

The sample consisted of 40 parents 21 to 56 years of age. All respondents were parents of children with ASD. The selection criterion for children was the diagnosis of autistic spectrum disorder based on medical documentation by a child psychiatrist or neurologist. The children were diagnosed with ASD between the ages of 3 and 4 . From the entire sample, 22 participants were parents of children receiving treatment at the Institute for Experimental Phonetics and Speech Pathology „Đorđe Kostić", Belgrade, Serbia, and 18 parents were members of the Association of parents of children with autism in Belgrade, Serbia. Table 1 presents parental characteristics with regard to sex, age, and educational level. Table 2 presents children's characteristics with regard to age, expressive language development, receptive language development, and verbal communication development. 
Specijalna edukacija i rehabilitacija (Beograd), Vol. 16, br. 4. 445-463, 2017.

Table 1 - Parental characteristics $(N=40)$

\begin{tabular}{llcc}
\hline & & $\mathrm{N}$ & $\%$ \\
\hline \multirow{2}{*}{ Sex } & male & 20 & 50 \\
\cline { 2 - 4 } & female & 20 & 50 \\
\hline \multirow{3}{*}{ Age } & $<30$ & 9 & 22.50 \\
\cline { 2 - 4 } & $30-40$ & 13 & 35.50 \\
\cline { 2 - 4 } & $>40$ & 18 & 45 \\
\hline \multirow{2}{*}{ Education level } & secondary & 25 & 62.50 \\
\cline { 2 - 4 } & faculty & 15 & 37.50 \\
\hline
\end{tabular}

Table 2 - Children's characteristics $(N=20)$

\begin{tabular}{lccc}
\hline \multirow{4}{*}{ Age } & & $\mathrm{N}$ & $\%$ \\
\hline & $<4$ & 6 & 30 \\
\cline { 2 - 4 } & $4-7$ & 9 & 45 \\
\cline { 2 - 4 } Expressive language & $>7$ & 5 & 25 \\
\cline { 2 - 4 } & yes & 8 & 40 \\
\hline \multirow{2}{*}{ Receptive language } & no & 12 & 60 \\
\cline { 2 - 4 } & no & 10 & 50 \\
\hline \multirow{2}{*}{ Communication } & yes & 6 & 50 \\
\cline { 2 - 4 } & no & 14 & 70 \\
\hline
\end{tabular}

Instruments and procedures

In this study, we used the Parental Stress Scale (Berry \& Jones, 1995). Parental Stress Scale (PSS) is developed as an alternative to the 101-item Parenting Stress Index (Abidin, 1995) and includes both positive and negative aspects of parenting. This is a measure of "individual differences in the level of stress associated with raising children" (Berry \& Jones, 1995, p. 465). It is an 18-item self-report scale and uses a Likert style rating scale. The Parental Stress Scale was found by Berry and Jones (1995) to correlate with the Perceived Stress Scale (Kohen, Kamarck \& Mermelstein, 1983) with $\mathrm{r}=0.41$ and the Parental Stress Index $(\mathrm{r}=0.75)$, and it was also 
able to differentiate between a clinical sample (mothers of children receiving treatment services for behavior problems) and a nonclinical sample (mothers of children not receiving treatment), with an effect size of Cohen's $d=0.72$. Its reliability (Cronbach's alpha) was 0.83. In PSS respondents agree or disagree in terms of their typical relationship with their child or children. The participants rate their agreement with each statement on a scale from 1 to 5 . Ratings are as follows: 1 strongly disagree; 2 - disagree; 3 - undecided; 4 - agree; 5 completely agree. The items 3, 4, 9-16 are scored according to the evaluation, while the items 1,2, 5-7, 17 and 18 are scored on reverse values (score $1=5,2=4,3=3,4=2,5=5$ ). The minimum score is 18 and the maximum is 90 . A higher score indicates the higher level of parental stress.

The data on verbal abilities of the sample was based on parental report. The parents received a short questionnaire in which they were asked about the level of their child's verbal skill. This questionnaire was created by authors of the study for the purpose of this research. The questionnaire was divided into four sections. The first section comprised general demographic data (parental age, sex and educational level, as well as child's age). The second section comprised data regarding child's language comprehension and it consists of four questions (verbal instructions from everyday communication at home: "Give me the car.", "Stop doing that.", "Come here", "Are you hungry?", "Can you give the ball to daddy?"). The third section comprised data regarding child's expressive language ability and it contains three questions ("Does your child produce any words?", "Does your child name objects on demand or spontaneously?", "Does your child sing songs?"). Finally, the fourth section that consists of three questions comprised data regarding existence of functional verbal communication within social context ("Does your child verbally ask for something that he wants?", "Does your child verbally express his basic needs?", "Does your child give a verbal response to your questions?"). Two or more positive answers in each section were inclusion criteria of the child in one of the two strata (acquired/not acquired). 
The participants were given questionnaires with full instructions on how to answer. In order to respect the anonymity of the parents and thus achieve a high level of questionnaire candor, they were asked to insert the answers in the designated box, after completing it.

Table 3 presents parental stress level based on parental characteristics. ANOVA test found no effect of parental sex $(\mathrm{p}=0.371)$ or parental age $(\mathrm{p}=0.263)$ on the stress level. There is a trend of increasing stress level with the increase in parental age. However, post hoc Bonferroni correction also found no differences between three parental age groups (with close to significant difference between $<30$ and $>40$ age groups $\mathrm{p}=0.62$ ), so it can be observed only as a trend. ANOVA test found significant effect of parental education level on the stress level $(\mathrm{p}=0.005)$.

Table 3 - Parental stress level based on parental characteristics

\begin{tabular}{|c|c|c|c|c|c|}
\hline & & M & SD & $\mathrm{F}$ & $\mathrm{p}$ \\
\hline \multirow{2}{*}{ Sex } & male & 37.1 & 11.60 & \multirow{2}{*}{0.82} & \multirow{2}{*}{0.371} \\
\hline & female & 40.4 & 11.97 & & \\
\hline \multirow{3}{*}{ Age } & $<30$ & 35.78 & 11.98 & \multirow{3}{*}{1.383} & \multirow{3}{*}{0.263} \\
\hline & $30-40$ & 36.23 & 8.58 & & \\
\hline & $>40$ & 42.06 & 12.75 & & \\
\hline \multirow{2}{*}{$\begin{array}{l}\text { Education } \\
\text { level }\end{array}$} & element/secon. & 42.6 & 11.23 & \multirow{2}{*}{9.01} & \multirow{2}{*}{0.005} \\
\hline & faculty & 32.33 & 9.03 & & \\
\hline
\end{tabular}

Note: parental age in years; element/second - educational level lower than a higher education or faculty, faculty - bachelor, master, $\mathrm{PhD}$; exact $\mathrm{p}$ value is present (based on the $\mathrm{F}$ value - ANOVA, confidence interval 95\%)

Table 4 presents parental stress level based on child characteristics. ANOVA test found no effect of child age on the stress level $(p=0.226)$. However, it can be seen that there is an increasing stress level with the increase in child age but without statistically significant difference between three age groups. Also, no effect of expressive language development on the stress 
level was found $(\mathrm{p}=0.107)$. ANOVA test found significant effect of receptive language development (speech comprehension) $(p=0.008)$ as well as the effect of communication skills (does child use a verbal language to communicate) $(\mathrm{p}=0.015)$ on the stress level.

Table 4 - Parental stress level based on child characteristics

\begin{tabular}{|c|c|c|c|c|c|}
\hline & & $M$ & SD & $\mathrm{F}$ & $\mathrm{p}$ \\
\hline \multirow{3}{*}{ Age } & $<4$ & 36.59 & 9.15 & \multirow{3}{*}{1.547} & \multirow{3}{*}{0.226} \\
\hline & 4-7 & 38.13 & 13.29 & & \\
\hline & $>7$ & 45.42 & 11.34 & & \\
\hline \multirow{2}{*}{ Expressive language } & yes & 35.5 & 11.59 & \multirow{2}{*}{2.731} & \multirow{2}{*}{0.107} \\
\hline & no & 41.41 & 10.97 & & \\
\hline \multirow{2}{*}{ Receptive language } & yes & 36.23 & 10.02 & \multirow{2}{*}{7.798} & \multirow{2}{*}{0.008} \\
\hline & no & 47.44 & 12.55 & & \\
\hline \multirow{2}{*}{ Verbal communication } & yes & 32.86 & 10.37 & \multirow{2}{*}{6.448} & \multirow{2}{*}{0.015} \\
\hline & no & 41.92 & 10.97 & & \\
\hline
\end{tabular}

Note: exact $\mathrm{p}$ value is present (based on the F value - ANOVA, confidence interval 95\%)

The final level of analyses was to test the predictive effect of a model using variables that had statistically significant effect on the parental stress level as predictors (parental education level, child's receptive language, and child's communication). There were two models. The first model was constructed using parental education level and child's receptive language as predictors. The second model was constructed using parental education level and child's communication as predictors. We did not combine child's receptive language and child's communication in one model as they were correlated with high collinearity (VIF factor $>2.0$ ).

A Linear regression analysis (enter method) showed that the first model had a significant predictive power: collinearity test - VIF factor $<1.1, \mathrm{R}=0.529, \mathrm{R}^{2}=0.280, \mathrm{R}^{2}$ Adjusted $=0.241$, $\mathrm{F}(2,37)=7.194, \mathrm{p}=0.002$. When each variable was observed separately, there was significant predictive effect of parental education level: Unstandardized $\mathrm{B}=8.126(\mathrm{SD}=3.422), \mathrm{t}=2.374$, $\mathrm{p}=0.023$, as well as child's receptive language development: Unstandardized $\mathrm{B}=8.452(\mathrm{SD}=3.968), \mathrm{t}=2.130, \mathrm{p}=0.04$. 
Specijalna edukacija i rehabilitacija (Beograd), Vol. 16, br. 4. 445-463, 2017.

\section{DISCUSSION}

In our study, we examined the stress levels in parents of children with ASD in relation to gender, education, age of parents, the child's age and speech-language skills. Our results showed no differences in the level of stress between mothers and fathers of children with ASD. Our findings corroborate the Davis and Carter (2008) and Hastings et al. (2005) studies, but not the Keen, Couzens, Muspratt and Rodger (2010) which found differences in stress level between mothers and fathers. One study found that paternal stress is not associated with child characteristics (Hastings et al., 2005). Dabrowska and Pisula (2010) investigated stress level in parents of children with ASD, Down sy and typical development and found that there were gender difference in parents of children with ASD, but not in other two groups. Milačić Vidojević (2008) found no differences in stress level between mothers and father of children with ASD. The author concluded that stress level was equal within mothers and fathers because of similar distribution of duties (both parents were employed and shared responsibilities regarding their child).

These findings tell us that in the case of application of specific interventions in the area of parents' mental health, equal attention should be given to fathers and mothers. However, more research is needed to discover and accurately determine any factor that may cause greater stress in fathers vs. mothers, in order to help parents in the most effective way.

Parents older than 40 showed higher levels of stress than younger parents, but the difference determined in our study did not show statistical significance, and we cannot conclude that these parents were under a greater deal of stress. Due to the sample size of this study and the difference between stress levels, it is possible that the research, if conducted on a larger sample, would show different results.

The results of our study showed no difference in thelevel of stress among parents of children of different ages. Meirsschaut 
et al. (2010) came to similar findings. When they examined the stress in mothers of children with ASD, the authors found no effect of child's age on maternal stress level. Similar results were also found in a study of McStay et al. (2014) who reported no effect of child's age on parental stress level when they added quality of life and behavioral problems into the regression model. These findings point to the importance of providing support to families of children with ASD regardless of the age of the child. Milačić Vidojević (2008) found the effect of child's age on parental stress level. The author found higher level of stress in parents of older children. The author explained this finding by parental awareness of the permanence of the disorder, lack of services for older children as well as the discrepancy between child's and parental needs. Our sample consisted of $25 \%$ of children older than 7 . This might be the reason why we found no effect of children's age on parental stress level. If our sample comprised more children older than 7 (those who were preparing to start school), we speculate that the results would be different.

Our results showed that parents with lower education experience greater stress than parents with higher education. This result can be linked to the findings of Ogston et al. (2011) which show that parents of children with ASD were under greater stress than parents of children with other types of disabilities because there are no clearly defined forms of treatment that are the most effective for this developmental disorder, so parents need to further inform themselves and make decisions. It is expected that parents with higher education are more informed and that their stress level is affected less by this aspect of the problem. However, in contrast to our findings, Dabrowska and Pisula (2010) showed that the level of parent's education represented a valid predictor of the level of stress, but found opposite results. In their study parents with higher education showed a higher level of stress. They explained their results with the fact that higher educated parents are more aware of difficulties that their child has and that can be expected in the future. Phetrasuwan and Shandor 
Miles (2009) reported that less educated mothers with lower income had higher level of stress. The authors explained that this finding might be associated with less access to support and other resources of information.

Speech and language skills are an important component of social communication, which is one of the aspects that is the most affected in people with ASD. When a child does not understand speech and cannot speak, it is hard for parents to find a way to communicate with their child. The child's understanding of speech facilitates the functioning of the family.

McStay et al. (2014) investigated stress level in parents of children with ASD and found no association with verbal abilities of the child. In contrast, Phetrasuwan and Shandor Miles (2009) found that verbal communication deficits in children with ASD had great impact on parental stress level. Tomanik et al. (2004) investigated child's behavioral factors that influence maternal stress and found that child's limited ability to communicate with others had a significant effect on mother's stress level. Our results show a higher level of stress for parents of children who did not understand speech. In children with ASD speech frequently does not reach the level of functionality. These children sometimes learn how to produce words at the level of repetition, naming pictures or even higher levels of language, but due to the deficit of social communication do not learn to communicate by speech. Developed speech and language abilities of a child enable a parent to communicate verbally with their child and to understand the child's desires and needs. The results of our study showed that undeveloped verbal communication of children led to higher level of parental stress. In line with our finding is the study that showed that children's limited ability to communicate represented a significant source of stress for their mothers (Tomanik et al., 2004). However, this study showed no association between stereotypic behavior and inappropriate speech (two domains of Aberrant Behavior Checklist) and maternal stress. The authors concluded that it 
might be that these behaviors were less distressing to mothers, especially when their children were young so such behaviors were more easily excused. In addition, the authors state that these behaviors may become more distressing to parents as the child grows older and language delays become more apparent. We need to note here that $30 \%$ of children in our sample were less than 4 years old which might have influenced our findings.

The limitations of our study are small sample size and lack of a control group. Differences in average points achieved between certain groups which still have not shown statistical significance that would allow us to make some conclusions, lead us to the idea that if the research had been conducted on a larger sample it could have led to different results. Checking the level of stress in parents of children with ASD indicates which of the characteristics of the parent or child should be or should not be given special attention during therapeutic work. Inclusion of the control group that would be composed of parents of children with typical development would continue to reveal specifics of parents of children with ASD.

\section{CONCLUSION}

Raising a child with ASD is a source of major stress for parents and the entire family. Various professionals such as therapists, psychologists, speech therapists, counselors and teachers participate in the habilitation and rehabilitation of families of children with ASD. The stress of parents can significantly complicate and slow down the process. It is important to know that it is equally necessary to support fathers and mothers, parents of all ages, parents of children of all ages and different speech and language skills. Particular attention should be given to parents with lower education. Future studies should examine the factors that influence the level of stress specifically for this group. The findings could be implemented as efficiently as possible and interventions should be focused on the mental health of this category of 
parents. It is important for specific strategies of intervention to be derived from identified dimensions of child behavior (Gallagher \& Bristol, 1989) and parents characteristics that are of great importance to parental distress. It is important to recognize parental levels of stress for designing early teaching interventions for children, because it is shown that it has great impact on child outcomes (Osborne, McHugh, Saunders \& Reed, 2008). Costa, Steffgen, and Ferring (2017) emphasize the importance of parents' evaluation and appraisals and thus underline the potential of cognitive-behavioral trainings aiming at improving parents' well-being and reducing their stress. The Serbian health system pays little attention to mental health of parents of children with ASD, which is not the case for many developed countries, focusing precisely on this issue. The existence of programs focused on stress of parents would surely lead to more constructive and more stable families, and hence to more advanced development of the child.

\section{REFERENCES}

1. Abidin, R. (1995). Parenting stress index, 3rd ed.. Florida: Psychological Assessment Resources Inc.

2. American Psychiatric Association. (2013). Diagnostic and statistical manual of mental disorders, 5th ed.. London: New School Library.

3. Berry, J. D., \& Jones, W. H. (1995). The Parental Stress Scale: Initial psychometric evidence. Journal of Social and Personal Relationships, 12, 463-472.

4. Costa, A., Steffgen, G., \& Ferring, D. (2017). Contributors to wellbeing and stress in parents of children with autism spectrum disorder. Research in Autism Spectrum Disorders, 37, 61-72. doi. org/10.1016/j.rasd.2017.01.007

5. Dabrowska, A., \& Pisula, E. (2010). Parenting stress and coping styles in mothers and fathers of pre-school children with autism and Down syndrome. Journal of Intellectual Disability Research, 54(3), 266-280. doi: 10.1111/j.1365-2788.2010.01258.x 
6. Davis, N. O., \& Carter, A. S. (2008). Parenting stress in mothers and fathers of toddlers with autism spectrum disorders: Associations with child characteristics. Journal of Autism and Developmental Disorders, 38(7), 1278-1291. pmd:18240012. doi:10.1007/s10803007-0512-Z

7. Duarte, C. S., Bordin, I. A., Yazigi, L., \& Mooney, J. (2005). Factors associated with stress in mothers of children with autism. Autism, 9(4), 416-427. pmid:16155057. doi: 10.1177/1362361305056081

8. Eisenhower, A. S., Baker, B. L., \& Blacher, J. (2005). Preschool children with intellectual disability: Syndrome specificity, behaviour problems, and maternal well-being. Journal of Intellectual Disability Research, 49(Pt 9), 657-571. pmid:16108983. doi: 10.1111/j.1365-2788.2005.00699.x

9. Estes, A., Munson, J., Dawson, G., Koehler, E., Zhou, X., \& Abbott, R. (2009). Parenting stress and psychological functioning among mothers of preschool children with autism and developmental delay. Autism, 13(4), 375-387. doi: 10.1177/1362361309105658

10. Gallagher, J. J., \& Bristol, M. (1989). Families of Young Handicapped Children. In M. C. Wang \& H. J. Walberg (Eds.), Handbook of Special Education: Research and Practice. 3rd ed.. pp. 295-317. New York: Pergamon.

11. Hastings, R. P., \& Johnson, E. (2001). Stress in UK families conducting intensive home-based behavioral intervention for their young child with autism. Journal of Autism and Developmental Disorders, 31(3), 327-336.

12. doi.org/10.1023/A:1010799320795

13. Hastings, R. P., Kovshoff, H., Ward, N. J., Degli Espinosa, F., Brown, T., \& Remington, B. (2005). Systems analysis of stress and positive perceptions in mothers and fathers of pre-school children with autism. Journal of Autism and Developmental Disorders, 35(5), 635-644. doi: 10.1007/s10803-005-0007-8

14. Ingersoll, B., \& Hambrick, Z. (2011). The relationship between the broader autism phenotype, child severity, and stress and depression in parents of children with autism spectrum disorders. Research in Autism Spectrum Disorders, 5(1), 337-344. doi: 10.1016/j.rasd.2010.04.017 
Specijalna edukacija i rehabilitacija (Beograd), Vol. 16, br. 4. 445-463, 2017.

15. Keen, D., Couzens, D., Muspratt, S., \& Rodger, S. (2010). The effects of a parent-focused intervention for children with a recent diagnosis of autism spectrum disorder on parenting stress and competence. Research in Autism Spectrum Disorders, 4(2), 229241. doi 10.1016/j.rasd.2009.09.009

16. Klinger, L., Dawson, G., \& Renner, P. (2002). Autistic disorder. In E. Mash \& R. Barkley (Eds.), Child psychopathology. 2nd ed.. New York: Guilford Press.

17. Kohen, S., Kamarck, T., \& Mermelstein, R. (1983). A global measure of perceived stress. Journal of Health and Social Behavior, 24, 385-396.

18. Konstantareas, M. M., \& Papageorgiou, V. (2006). Effects of temperament, symptom severity and level of functioning on maternal stress in Greek children and youth with ASD. Autism, 10(6), 593-607. doi: 10.1177/1362361306068511

19. Kuhl, P. K., Coffey-Corina, S., Padden, D., \& Dawson, G. (2005). Links between social and linguistic processing of speech in preschool children with autism: Behavioral and electrophysiological measures. Developmental Science, 8(1), 1-12. pmid:15647058. doi: 10.1111/j.1467-7687.2004.00384.x

20. McStay, R. L., Dissanayake, C., Scheeren, A., Koot, H. M., \& Begeer, S. (2014). Parenting stress and autism: The role of age, autism severity, quality of life and problem behaviour of children and adolescents with autism. Autism, 18(5), 502-510. doi: $10.1177 / 1362361313485163$

21. Meirsschaut, M., Roeyers, H., \& Warreyn, P. (2010). Parenting in families with a child with autism spectrum disorder and a typically developing child: Mothers' experiences and cognitions. Research in Autism Spectrum Disorders, 4, 661-669. doi: 10.1016/j. rasd.2010.01.002

22. Milačić Vidojević, I. (2008). Stres kod roditelja dece sa autizmom. Psihijatrija danas, 40(1), 37-49.

23. Ogston, L. P., Machintosh, V. H., \& Myers, J.B. (2011). Hope and worry in mothers of children with an autism spectrum disorder or Down syndrome. Research in Autism Spectrum Disorders, 5, 1378-1384. doi: 10.1016/j.rasd.2011.01.020 
24. Phetrasuwan, S., \& Shandor Miles, M. (2009). Parenting stress in mothers of children with autism spectrum disorders. Journal for Specialists in Pediatric Nursing, 14(3), 157-165. doi:10.1111/j.17446155.2009.00188.x

25. Tomanik, S., Harris, G., \& Hawkins, J. (2004). The relationship between behaviours exhibited by children with autism and maternal stress. Journal of Intellectual \& Developmental Disability, 29(1), 16-26. doi.org/10.1080/13668250410001662892

26. Wachtel, K., \& Carter, A. S. (2008). Reaction to diagnosis and parenting styles among mothers of young children with ASDs. Autism, 12(5), 575-594. pmid:18805948. doi: $10.1177 / 1362361308094505$ 


\title{
ISPITIVANJE FAKTORA STRESA KOD RODITELJA DECE SA AUTISTIČKIM SPEKTROM POREMEĆAJA
}

\author{
Nina Stanojević, Vanja Nenadović, ${ }^{* * *}$, Saška Fatić, Miodrag Stokić, ${ }^{* * * *}$ \\ ${ }^{*}$ Centar za unapređenje životnih aktivnosti, Beograd, Srbija \\ "Institut za eksperimentalnu fonetiku i patologiju govora "Đorđe Kostić", \\ Beograd, Srbija
}

\section{Sažetak}

Pored poteškoća u oblasti socijalne interakcije i komunikacije, deca sa autističkim spektrom poremećaja (ASP) ispoljavaju ponašanje koja ometa svakodnevne aktivnosti, što može dovesti do teškoća u funkcionisanju uže i šire porodice. Ograničene socijalne, emotivne i komunikativne sposobnosti dece sa ASP, njihov neujednačen kognitivni razvoj i maladaptivno ponašanje su izvor stresa za roditelje.

Cilj našeg istraživanja bio je da se proceni nivo stresa kod roditelja dece sa ASP u odnosu na pol, uzrast, obrazovanje i starost roditelja kao i u odnosu na govorno-jezičke sposobnosti deteta (ekspresivni/ receptivni govor, upotreba govora u službi komunikacije). Uzorak je činilo 40 roditelja (20 majki i 20 očeva) starosti od 21 do 56 godina. Svi ispitanici su bili roditelji dece sa ASP, od kojih je 22 roditelja dece koja su na tretmanu u Institutu za eksperimentalnu fonetiku i patologiju govora "Đorđe Kostić" i 18 roditelja koji su članovi Udruženja roditelja dece sa autizmom. U ovoj studiji, koristili smo Skalu za procenu nivoa roditeljskog stresa (Parental Stress Scale - Berry \& Jones, 1995). Rezultati pokazuju da ne postoje statistički značajne razlike u nivou roditeljskog stresa u odnosu na pol i starost roditelja, uzrast deteta i razvijenost ekspresivnog govora. Na nivo roditeljskog stresa dece sa ASP značajno utiču nivo obrazovanja roditelja $(\mathrm{p}=0,005)$, razvijenost receptivnog govora $(\mathrm{p}=0,008)$, i razvijenost verbalne komunikacije kod deteta $(\mathrm{p}=0,015)$. Niži obrazovni nivo i teškoće u produkciji i razumevanju govora kod deteta mogu da budu uzrok višeg nivoa roditeljskog stresa. Primenom linearne regresije utvrđeno je da stepen obrazovanja roditelja i razvijenosti razumevanja (receptivni govor) govora kod deteta, kao prediktori predstavljaju statistički značajno prediktivan model kojim se može predvideti nivo roditeljskog stresa. Roditeljski stres može značajno komplikovati i usporiti proces rehabilitacije deteta. Važno je 
znati da je pomoć i podrška podjednako potrebna roditeljima različitih starosnih grupa, roditeljima dece različite starosti i različitih verbalnih sposobnosti. Posebno je potrebna podrška i pomoć roditeljima nižeg obrazovanja.

Ključne reči: autistički spektar poremećaja, roditeljski stres, komunikativne sposobnosti dece

Primljeno: 28.04.2017.

Prihvaćeno: 22.09.2017. 